\title{
Human Rights through Literature: A Proposed Course for Students of Department of English, Faculty of Arts, Taiz University, Yemen
}

\author{
Abdulrahman Mokbel Mahyoub Hezam \\ Department of Languages and Translation, Faculty of Science and Arts, Taibah University, Al-Ola, \\ KSA \\ arahmanhezam@gmail.com
}

\begin{abstract}
The study aims at examining how the two disciplines such as literature and human rights can inform each other for the common purpose of bringing human rights into life of common people to ensure their basic rights. The significance of the study lies in trying to design a course for students of English language, Faculty of Arts, Taiz University. The course tries to combine human rights and literature for students of a country suffering from war and social and political unrest. The paper explores how we can create awareness among students and motivate them to be active members in society. It combines the theoretical and the practical taking literature from the pages of the novels, lines of poetry and drama into reality to make students active participants in society.
\end{abstract}

Keywords: course design, Human rights literature, Yemen,

\section{LiterATURE REVIEW}

"Human rights" refers to the basic rights and freedoms such as the right to life and liberty, freedom of thought and expression, and equality before the law. Wikipedia defines human rights as" are moral principles or norms, ${ }^{[1]}$ which describe certain standards of human behavior, and are regularly protected as legal rights in municipal and international law. ${ }^{[2]}$ They are commonly understood as inalienable ${ }^{[3]}$ fundamental rights "to which a person is inherently entitled simply because she or he is a human being," ${ }^{[4]}$ and which are "inherent in all human beings" ${ }^{[5]}$ regardless of their nation, location, language, religion, ethnic origin or any other status. ${ }^{[3] "}$

We all know the power of literature as a source of transformation not only in the mind of the reader but also in society in general. Literature does have the power to change lives. Literature has a unique power to touch the hearts and minds and engage readers in a way that is distinctly different from other texts. It has the capacity to drive change and motivate people to take action.

Literature can cultivate a better understanding of Human Rights through critical evaluation of characters, analysis of scenarios, and examination of diverse historical voices. Students will not only gain pragmatic skills for critical reading, but will also begin to understand their responsibility in creating change while realizing they are accountable for their actions. "(Cockrill, Thematic Unit)

Through literature people can find their place in the world, feel they belong and discover their sense of responsibility. Today's understanding of human rights was created through various factors and no one can deny the role played by certain forms of literature in forming this concept of human rights. Naturally, literature can be used to promote human rights in undeveloped countries and create awareness among the young generation.

All literary genres deal with human rights issues, and thus - directly or indirectly - promotes values of human rights. The goal of this course on human rights through literature is to combine the literary driving force with motivating students for action. The course is based on the belief in the enormous power of literature to drive change, and create awareness among people of their rights and the rights of others. One main objectives of this course is the representation of human rights violations as a social problem and pointing out how reforming society is both urgent and necessary. In order to explore this dilemma, this course focuses on the intersection between human rights advocacy and the 
various cultural forms that explicitly attempt to participate in human rights discourse. Through studying poems, novels, drama and short stories that reflect on the atrocities of slavery, oppression of women, racial discrimination and inequality, the course aims to create awareness among students of the need for a new outlook. Furthermore, the course will try to turn ideas about human rights into actions and motivate students to actively participate in reforming society and reduce the level of human rights violations.

Yemeni society needs a lot of action to combat human rights violations and change the lot of many people who live miserable life due to wrong tribal, social and cultural practices. Human rights through literature as a course will help students become committed to their society help them believe that each one of them has moral duty and power to make a social change. It is based on the belief of the enormous power of literature to make a positive change and in the responsibility of every member toward society.

Of all the literary forms, fiction is perhaps the most closely related to social and political reality and the most useful in advocating human rights . As Rockwell says, "the patterned connection between society and fiction is so discernible and so reliable that literature ought to be added to the regular tools of social investigation" (3). Bradbury sees the novel as "a mode of inquiry into the knowable, analogous in its empirical modes, and methods to other forms of written inquiry" (11). Balzac has defined the novel as "the private history of nations". This definition points out the relation between the novel as a literary genre and the national identity. Undoubtedly the scope, subject matter and structure of the novel makes it "more than other literary forms, exposed to the facts of a time, the articulable relationships of a time, the ways of knowing a time, [and] the ideological interpretation of a time" (Bradbury 13). The relationship between the novelist and his age is stressed by Edward Said who believes that, "Every novelist is of his time, however much his imagination may take him beyond it" ("Arabic Prose" 42-3). In other words novelists cannot escape from the political, social and intellectual realities of their society. "[A] writer has no choice", Ngugi Wa Thiong'o wrote in his preface to Writers in Politics, "whether or not he is aware of it, his works reflect one or more aspects of the intense economic, political, cultural and ideological struggles in society." The writer must meet the challenge of his time and strive to tell the people the truth of the time, and reflect in his works the sense and spirit of the time that shaped his sensibility. He must give articulation to "the consciousness of his time that he shares with the group of which historical circumstances, class, period, perspective makes him a part" (Said, "Arabic Prose" $42-3$ ). Through analysis of a variety of human rights storytelling genres that reflect a range of contexts, this course will suggest that it is impossible to understand human rights without also thinking about the stories that create and sustain their idea.

Poetry is also a powerful means through which poets strive to make change in their society. In the Arab World, poetry was always associated with freedom movements and the struggle against colonialism in the $20^{\text {th }}$ century. It can, then, be used to spread awareness of human rights. There are many ways in which human rights issues can be successfully voiced through poetry. Poetry can deal with racial discrimination, social injustice, child rights, etc," Poets can work as reporters - capturing protests, taking testimony - but they can also work as historians by linking up the stories of the past with themes in our present..............(Therefore) poetry can be a powerful human rights education tool "( Laila Sumpton, 83)In Arab countries in general poetry has been more effective than other forms of literature in dealing with human rights issues. Poetry can also serve as a tool for students to voice their feelings on human rights issues and generate empathy for national aqnd international struggles for human rights. Studying poetry by poets dealing with human rights concerns encourages students to explore different perspectives and aspects of human rights. It enhances critical thinking and encourages creative thought among students.

The proposed course on human rights through literature for Yemeni students is an attempt to combine the theoretical aspects of human rights with the practical aspects, helping students from learners into real activists who make positive change. The course is intended for students of the fourth year in the department of English who have already acquired language skills, writing skills, critical and analytical skills. 


\section{Course Profile}

\section{A. Course Details}

1. Course Name : Human Rights through Literature.

2. Course Code : L 412

3. Course Type : College Requirement course Mandatory Specialization course Optional Specialization Course
4. Teaching Hours : Theoretical ( 2 )
Practical
5. Introduction Time
: Fourth Year First semester

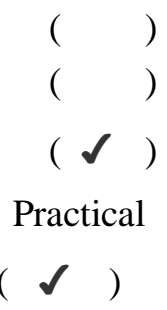

\section{B. Course Content Description}

The course enhances the students' understanding of human rights through introducing them to various literary texts that deal with human rights. The text can be poems, novels, dramas, essays, etc. students study these texts and analyse the human rights in the text. In addition to this students will do a lot of activities like writing, debating, and reporting.

\section{Course Goals}

1. General Goals

- Enhance students to be active citizens in their community, aware of their rights and the rights of others. and to foster awareness of responsible actions

- use the study of several genres of literature such as short story, novel, drama and poetry as a vehicle to explore various aspects Human Rights.

- Enabling students to become critical thinkers able to relate what they read to reality around them.

- Enhance students' language skills.

2. Objectives

- Making the students aware of meaning and significance of human rights.

- Students learn how to write articles and reports about human rights.

- Students are expected to be able to express their views on human rights freely and convincingly.

- Able to examine these rights in our community and discover human rights abuses in their society and try to fight them.

- Be able to work with local and international organizations that are interested in human rights.

- Able to Practice techniques of literary analysis.

- Able To develop and refine critical thinking, oral and written expression, and techniques of textual analysis.

- Able to develop communication skills in essays, class discussions, presentations, web discussions and research projects.

- To engage in collaborative learning and teamwork.

- Actively participate in the creation of a vibrant and rewarding learning community.

D. D. Course Content Structure

\begin{tabular}{|l|l|}
\hline Title of the Unit & Content of the Unit \\
\hline Introduction & $\begin{array}{l}\text { - Literature and Society. } \\
\text { - Literature and Human Rights. } \\
\text { - Students discuss the meaning of human rights and express their views individually } \\
\text { and in groups. }\end{array}$ \\
& $\begin{array}{l}\text { - How to do stylistics analysis in four steps } \\
\text { Homework: Write an article about human rights and their role in modern world. }\end{array}$ \\
\hline $\begin{array}{l}\text { Human Rights } \\
\text { Through }\end{array}$ & $\begin{array}{l}\text { Students are given short stories to read including } \\
\text { Fiction. The Grief by Chekhov }\end{array}$ \\
Short Stories & - The Postmaster by Tagore \\
\hline
\end{tabular}




\begin{tabular}{|c|c|}
\hline & $\begin{array}{l}\text { Assignment: Students read a short story dealing with human rights and analyze how it } \\
\text { deals with human rights. }\end{array}$ \\
\hline Novel & $\begin{array}{l}\text { Students can select } \\
\text { - Oliver Twist- Charles Dickens. } \\
\text { - Madaq Alley- Naguib Mahfouz } \\
\text { - Untouchable - Mulk Raj Anand } \\
\text { - Invisible Man - Ralph Ellison } \\
\text { - The grapes of Wrath - John Steinbeck } \\
\text { - Animal Farm- George Orwell } \\
\text { Students read the novels and focus on human rights abuses and discuss the social themes } \\
\text { like injustice, exploitation, inequality... etc. } \\
\text { Students can also watch a movie which focuses on human rights. } \\
\text { 1- Seven Years in Tibet. } \\
\text { Students answer the quiz given to them and debate certain issues related to the movie's } \\
\text { content. } \\
\text { Assignment: write a report on status of human rights in your area, city or country. }\end{array}$ \\
\hline $\begin{array}{l}\text { Human Rights } \\
\text { Through Poetry }\end{array}$ & $\begin{array}{l}\text { Short discussion of reports written by students. } \\
\text { - Students are given selected poems dealing with human rights issues } \\
\text { 1- Hughes's "My Theme for English B". } \\
\text { 2- Auden's Unknown Citizen } \\
\text { 3- Blake's London } \\
\text { 4- Hughes's Sympathy } \\
\text { Homework: Student search for more poems which deal with human rights. }\end{array}$ \\
\hline $\begin{array}{l}\text { Human Rights } \\
\text { Through Drama }\end{array}$ & $\begin{array}{l}\text { - Use of drama to promote human rights and examine social issues. } \\
\text { - Discussion of some plays in general terms. A play or two can be selected for detailed } \\
\text { study. } \\
\text { 1- A Doll's House (Ibsen) } \\
\text { 2- The Crucible (Arthur Miller) } \\
\text { A discussion of the play } \\
\text { Students do some activities like debates, writing articles, issuing leaflets or wall- } \\
\text { magazines. }\end{array}$ \\
\hline Essays & $\begin{array}{l}\text { Students can read a number of essays dealing with human rights drawn from: } \\
\text { - Writings of world writers on human rights. } \\
\text { - Various newspapers, journals, magazines and websites. } \\
\text { - Landmark document on human rights. } \\
\text { Activities: } \\
\text { 1- Reading and analyzing the selected articles and essays. } \\
\text { 2- Writing paragraphs and articles on various issues. } \\
\text { 3- Carrying out imaginary and even real interviews. } \\
\text { 4- Formatting a website or an e-magazine dealing with human rights. }\end{array}$ \\
\hline
\end{tabular}

\section{E. Methodology}

1. Criteria of Instructor Selection

Area of specialization

Years of teaching experience

Special skills
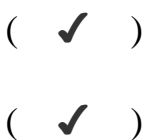

kills required for the course

Arabic language and research skills

English language and research skills

Computer skills

Other skills 
Human Rights through Literature: A Proposed Course for Students of Department of English, Faculty of Arts, Taiz University, Yemen

3. Teaching methods employed by the teacher

Lecturing

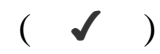

Classroom discussion

Brainstorming

Problem solving

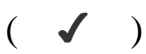

Presentations

Writing reports

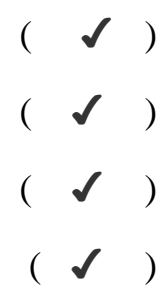

Others. Specify . Watching videos \& documentary films.

\section{F. Educational Resources (Human and Material) Required}

Specialist faculty

Non-specialist faculty

Visiting faculty

Laboratory technician

Assistant technician

Textbooks

Reference books

Computers

Software

Audio-visual aids

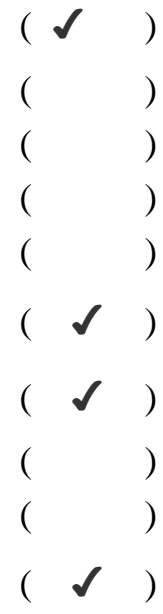

\section{G. Setting}

Place Timing

During part of the semester Throughout the semester

Lecture room

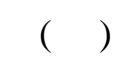

Multi-media room ( )
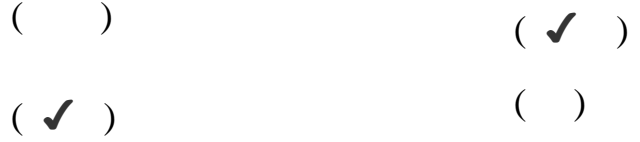

Laboratory

( )
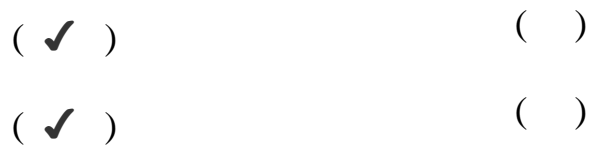

Computer lab

( )
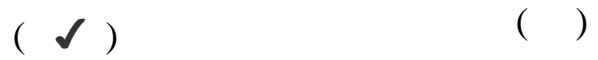

Others. Please specify

\section{H. Classroom activities}

Listening

Reading

Self-learning

Using a computer

Watching movies

Inviting an internal faculty

Inviting an external faculty 


$\begin{array}{lll}\text { Carrying out experiments } & ( & ) \\ \text { Carrying out field research } & (\checkmark & ) \\ \text { Making field visits } & (\checkmark & ) \\ \text { Case study } & (\checkmark & )\end{array}$

\section{Evaluation}

1. Marks Allocation and Timing

\begin{tabular}{|l|l|l|}
\hline Test/Assignment & Mark & Date(s) \\
\hline Pre-internal & 10 & \\
\hline Internal assessment 20\% & 20 & \\
\hline Pre-final & 10 & \\
\hline Final assessment 40\% & 40 & \\
\hline Assignments & 10 & \\
\hline Paper/Report & 10 & \\
\hline Total & 100 & \\
\hline
\end{tabular}

2. Types of Tests

Written test

Oral test

3. Types of Questions

Long essay questions

Short essay questions

Gap-filling questions

Binary choice items

Matching

Multiple-choice items

\section{J. Reference Books}

Specify the Arabic and non-Arabic reference books and, preferably, also specify the relevant chapter(s) and page number(s).

Non-Arabic reference books

1. Ibsen, Henrik, George Schaeffer, Julie Harris, Christopher Plummer, and Jason Robards. A Doll's House. New York, N.Y: MGM/UA, 1981. Vanka, Grief.

2. Hughes, Langston, Arnold Rampersad, and David E. Roessel. The Collected Poems of Langston Hughes. New York: Knopf, 1994. Print.

3. Orwell, George, Animal Farm, New York: Harcourt, Brace \& Co,1946. Print

4. King, Martin L., Jr. "I Have a Dream." Speech. Lincoln Memorial, Washington, D. C. 28 Aug. 1963. American Rhetoric. Web. 25 Mar. 2013.

5. Declaration of the Rights of Man and Citizen Approved by the National Assembly of France, August 26, 1789 http://www1.curriculum.edu.au/ddunits/downloads/pdf/dec_of_rights.pdf

6. Universal Declaration of Human Rights http://www.jus.uio.no/lm/un.universal.declaration.of. human.rights.1948/portrait.a4.pdf

7. Arabic reference books

1. The Holy Quran

2. Constitution of Republic of Yemen 


\section{CONCLUSION}

According to Eleni coundouriotis and Laurn M. E Goodlad "The multidisciplinary attention to human rights in the humanities and social sciences today explores the exchanges between political, legal, and ethical discourses on human rights and cultural texts including literature, the visual and performing arts, film, and popular culture" Literature can be a vehicle through which student's awareness of human rights is enhanced. It is through literature that we can understand the suffering of others and sympathize with them. Literature can also be an engine for change in society and it can transport readers to different times, distant places and various situations. Yemen is suffering from a lot of social problems, oppression, discrimination, injustices and other human rights violations. The first step in reforming Yemeni society is by creating a generation of learners who can have better understanding of the meaning and significance of human rights and who can through their knowledge try to change other segments of society.

The designed course on human rights through literature is very much needed in Yemeni universities. It is very important to help students develop this skill of empathy - a skill that is vital for hatred to diminish, coexistence to grow, inequality to vanish and human rights to flourish. The course will also introduce students to a range of critical methods and approaches to literary genres and forms and to enable students to develop skills in close reading, writing and argumentation in relation to a clearly defined thematic focus

Yemen is a country torn by war and dominated by sectarian feelings and extremist views. To combat this we need a comprehensive strategy to raise empathy, compassion and solidarity. One of the aspects of this strategy is education and incorporating human rights in the educational system. The designing of this course Human Rights through Literature is a step in that direction.

\section{REFERENCES}

Baxi, U. (1998). Voices of suffering and the future of human rights. Transnat'l L. \& Contemp. Probs. , 125.

Benedek, W. (2013). Understanding Human Rights: Manual on Human Rights Education. BWV, Berliner Wiss.-Verlag

Bradbury, M. (1973) Possibilities: Essays on the State of the Novel. London: Oxford University.

Cockrill J. Hall S.\& Long R., Thematic Unit: Understanding Human Rights through Literature, Retrieved from: http://smago.coe.uga.edu/VirtualLibrary/Cockrill_Hall_Long. pdfhttp://smago. coe.uga.edu/VirtualLibrary/Cockrill_Hall_Long.pdf

Coundouriotis, E. \& Laurn M. E Goodlad (2010)"Comparative Human Rights: Literature, Art, Politics"" Journal of Human Rights, 9:121-126,

Freedom: Stories Celebrating the Universal Declaration of Human Rights, (2011) Amnesty International USA Broadway

Francisco L. P. (2013): o. "The Transformative Power of Literature Today." English Quarterly 44.347-22.

Moore, A. Goldberg E. S. (2012) Theoretical Perspectives on Human Rights and Literature. Routledge

Ngugi wa Thiong'o, (1997).. Writers in Politics: A Re-engagement With Issues of Literature and Society, Oxford: James Currey

Rockwell, J.(1974) Fact in Fiction: The Use of Literature in the Systematic Study of Society. London: Routledge and Kegan Paul,.

Said, E.(2001). "Arabic Prose and Prose Fiction After 1948." Reflections on Exile and Other Literary and Cultural Essays. Delhi: Penguin Books India,. 41-60.

Sumpton, L.Poetry for human rights "http://sas-space.sas.ac.uk/6211/1/12sumpton.pdf May 23.

Wellek, R. \& Austin Warren.( 1974)Theory of Literature. Harmondsworth: Penguin. 


\section{AUTHOR'S BIOGRAPHY}

Abdul Rahman Mokbel Mahyoub Hezam, was born in 1974 in Ibb, Yemen .He received B.A. in English language from Faculty of Arts, Taiz University. M.A. in Literature from Delhi University in 2001 and $\mathrm{PhD}$ in literature from Panjab University, India in 2005.

$\mathrm{He}$ is an assistant professor of English literature in the department of English, Faculty of Arts, Taiz University He is currently head of the department of Languages and Translation, Faculty of Science and Arts, Taibah University, Al-Ola Campus, Kingdom of Saudi Arabia 